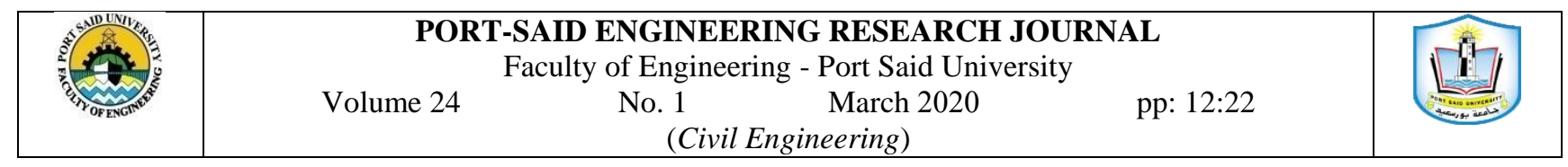

\title{
Behavior of RC Slabs subjected to Eccentric Punching Shear
}

Abanoub.S.Atallah',Ezzat A.Sallam²,Hassan M.Hassan ${ }^{3}$, and Emad.Y.Abdel.Galil4

\begin{abstract}
Eccentric punching shear loads most likely take place on flat plate floors. This type of structure has been investigated experimentally and analytically by many researchers. Most of those experimental studies have dealt with slab specimens as a free - edge supported. This testing technique audits, in turn, slab specimen edges to leave the free support when exposed to an eccentric shearing load. So, slab deformed shape, in this case, does not represent that of the real floor slab when subjected to eccentric shear loading. This work investigates the behavior of the slabs under eccentric punching shear loads with the most realistic different techniques of the true slab condition and certainly gives more accurate results. Flat plates with concrete dimensions $(600 \times 600 \times 60)$ $\mathrm{mm}$ were tested under variable eccentricities $(50-70-100) \mathrm{mm}$. Also, the effect of the flexure reinforcement ratio was studied. The ultimate load capacity, central deflection, cracking progress and pattern of cracks are recorded and discussed. The failure loads were compared to those calculated from different design codes. It was concluded that increasing eccentricity leads to a reduction of failure loads. Also increasing flexure reinforcement increases the failure loads. Moreover, it was observed that the expected failure loads from different design codes were lesser than the experimental results.
\end{abstract}

Keywords: punching shear loads, column slab connection, and edges condition.

\section{1- INTRODUCTION}

The most major design problem from the structural point of view for the flat slab system is the generated large flexure moment and shear forces transferred from slabs to columns. That pose a risk in flat plates because of the possibility of the existence of punching shear failure with rotations [1], [2].

1- Civil Engineering Department, Faculty of Engineering, Port Said,Egypt,email:abanoubsaad91@yahoo.com

2- Civil Engineering Department, Faculty of Engineering, Port Said,Egypt,email: ezat_sallam@yahoo.com

3- Civil Engineering Department, Faculty of Engineering, Port

Said, Egypt,email: dean_office@eng.psu.edu.eg

4- Civil Engineering Department, Faculty of Engineering, Port

Said,Egypt,email:emad0057@eng.psu.edu.eg

DOI: 10.21608/pserj.2020.20342.1021
Moment transfer from the slab to a column is always present in flat slabs due to the unequal nature of the loading, uneven distance and boundary conditions, application of lateral forces like wind or earthquake, temperature variations in the material, differential contraction between two plates, and development of creep conditions. $\square 3,10]$ This moment creates radial cracks which spread around the slab - columns connections and the failure occurs when the column punches through the slab that making the intersection between radial and diagonal cracks, and produced a pyramid failure surface which reduced the punching resistance of the flat slab as Figures $(1,2)$.

This research aims to study the behavior of flat plates exposed to punching forces with interior slab column connection. The study was undertaken by experimental and analytical investigations. The flat plate reinforced concrete structures do not include beams so that they can be able to transfer all loads acting on slabs to the columns directly [5]. 
From previous literature concerning the eccentric punching loads of flat plates, it was found that many researchers studied the behavior of slabs under eccentric punching loads with preventing the vertical compression displacement only. This technique allows the edges of slabs to uplift when exposed to eccentric punching loads.

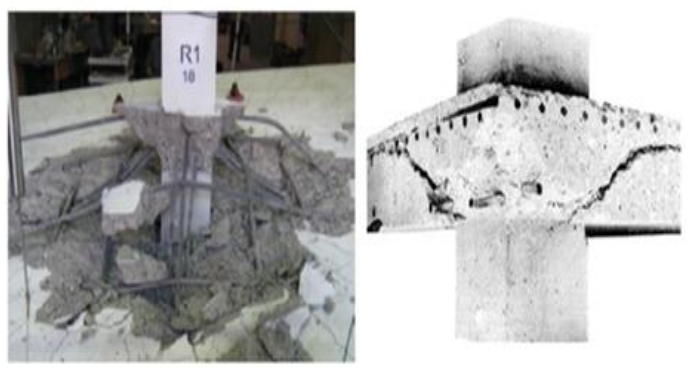

Figure (1): Punching shear localized failure with pyramid shape failure surface [5].

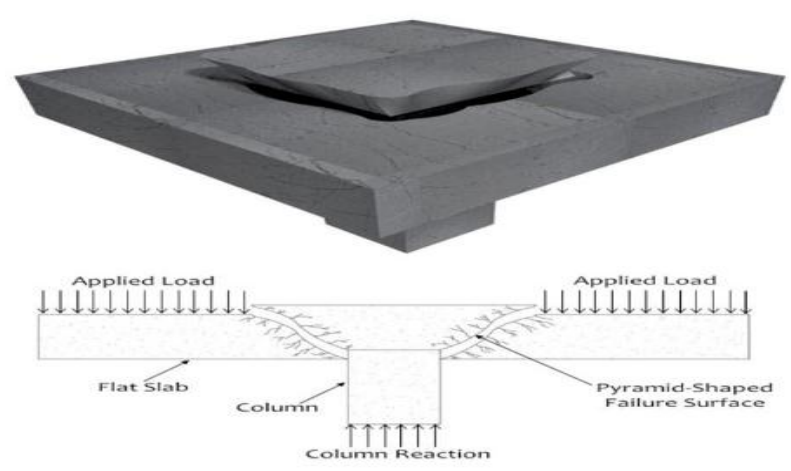

Figure (2): Punching shear failure [6].

\section{2- EXPERIMENTAL PROGRAM 2.1 Details of Test Specimens}

Eleven, scaled two-way slab, specimens were constructed and tested to failure. The tested specimens were interior slab-column connections with a $100 \mathrm{~mm}$ square column (type 1) extending $300 \mathrm{~mm}$ above the plate as shown in Figure(3). And another different shape of column (type2) as shown in Figure (4). All the slabs were reinforced with $11 \varnothing 5 \mathrm{~mm}$-diameter Mild steel bars in each direction (as a bottom mesh). Table (1) shows the characteristics of the tested slabs. Column stubs were reinforced with four deformed steel bars of 5 $\mathrm{mm}$ diameter, cut to length $10 \mathrm{~mm}$ less than the height of the column as Figures $((5),(6))$.

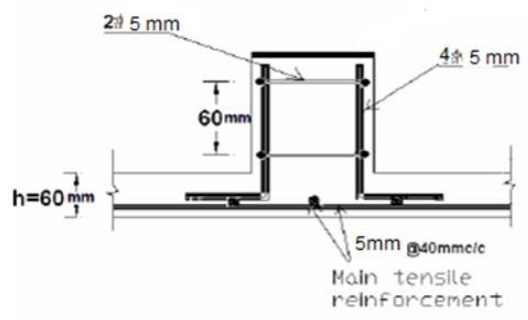

Figure (3): Details of reinforcement of column stubs Type (1)

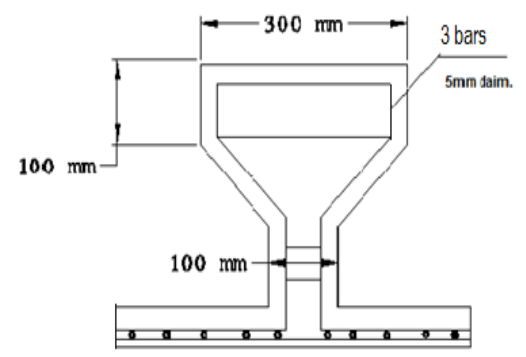

Figure (4): Details of reinforcement of column stubs Type (2)

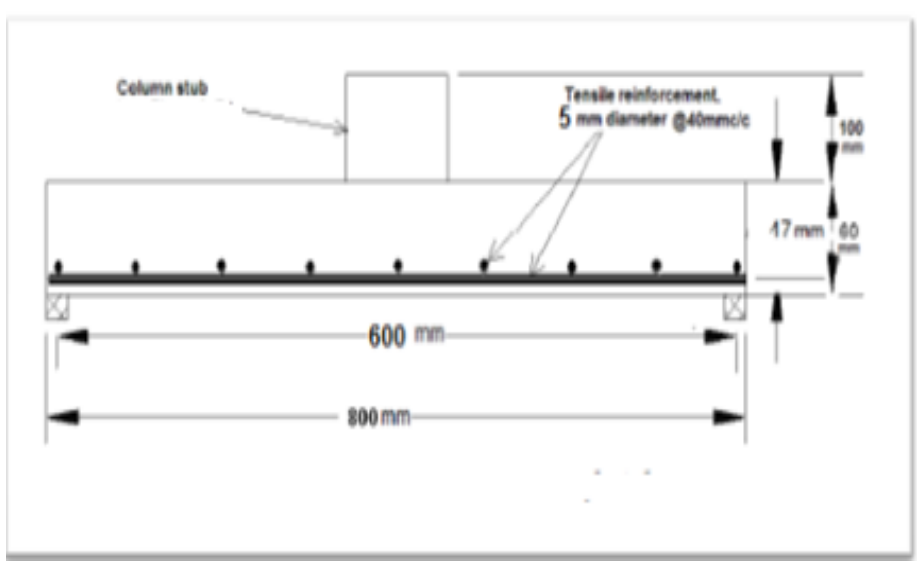

Figure (5): Tested slabs and details of reinforcement type (A)

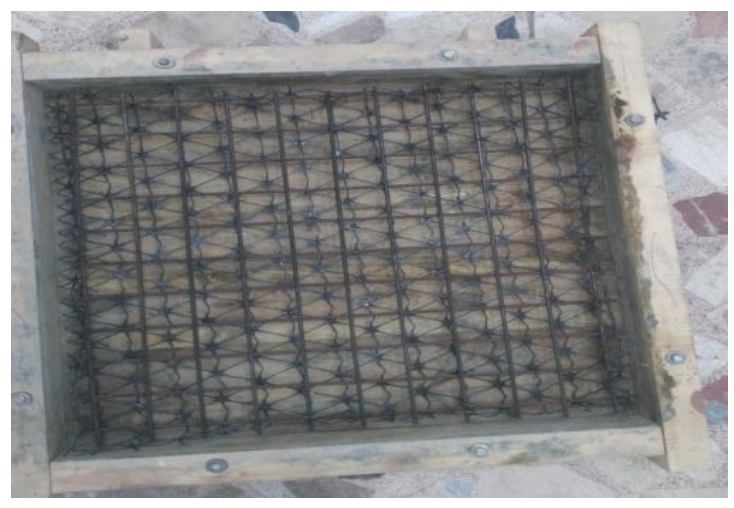

Figure (6): Tested slabs and details of reinforcement type $(\boldsymbol{B})$ 


\begin{tabular}{|c|c|c|c|c|}
\hline \multicolumn{5}{|c|}{ Table(1): The characteristics of the tested slab } \\
\hline $\begin{array}{l}\text { group } \\
\text { No. }\end{array}$ & $\begin{array}{l}\text { Sample } \\
\text { No. }\end{array}$ & $\begin{array}{l}\text { Fcu } \\
\text { Mpa }\end{array}$ & $\begin{array}{l}\text { Column } \\
\text { Type }\end{array}$ & $\begin{array}{l}\text { Flexure } \\
\text { Detailing } \\
\text { Type }\end{array}$ \\
\hline S 1 & S1 & 30 & No Column & (A) \\
\hline \multirow{3}{*}{ S2 } & S 21 & \multirow{3}{*}{30} & \multirow[t]{3}{*}{ No Column } & \multirow{3}{*}{ (B) } \\
\hline & S 22 & & & \\
\hline & S 23 & & & \\
\hline \multirow{3}{*}{ S3 } & S 31 & \multirow{3}{*}{30} & \multirow{3}{*}{$\begin{array}{c}\text { Type } \\
\text { (1) }\end{array}$} & \multirow[t]{3}{*}{ (A) } \\
\hline & S 32 & & & \\
\hline & S 33 & & & \\
\hline \multirow{4}{*}{ S4 } & S 41 & \multirow{4}{*}{30} & \multirow{4}{*}{$\begin{array}{l}\text { Type } \\
\text { (2) }\end{array}$} & \multirow{4}{*}{ (A) } \\
\hline & S 42 & & & \\
\hline & S 43 & & & \\
\hline & S 44 & & & \\
\hline
\end{tabular}

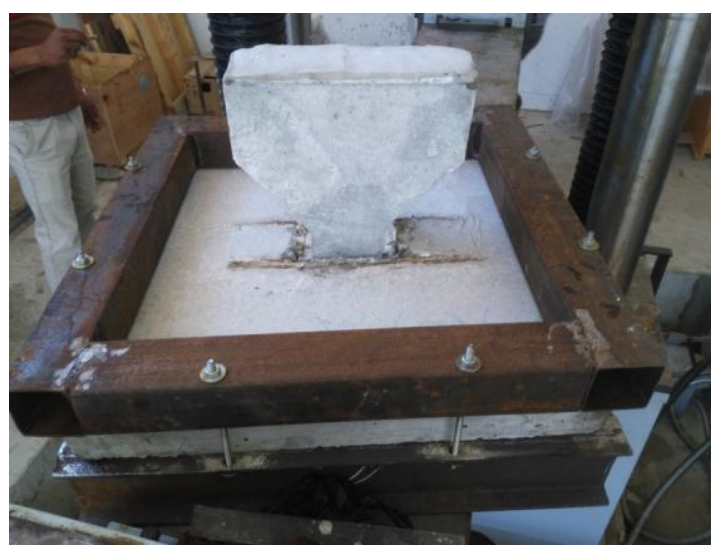

Figure (8): Preparing the slabs for testing

\section{3- DISCUSSION OF EXPERIMENTAL RESULTS}

The major purposes of the test program were to study the eccentric punching loads applied of the slab- column connection to determine the ultimate load capacity for punching shear force, the difference of cracks patterns for each tested slabs and the area of the shear crack perimeter.

\subsection{Load deflection curves}

Table (2) discuses a conclusion results of the failure load, the ultimate deflection at failure load and the deflection at the first crack load, the range of first cracking load (Vfirst) was (15-40)\%from the ultimate failure load capacity. The first slab of each group was a control slab.

1. For series (S2) the punching failure load increased by $(20-40) \%$ and the observed maximum deflection reduced by(3.6-11.7)\% for slabs (S22S23) respectively as Figure (9).

2. For series (S3) the punching failure loads decreased by $(11-17) \%$ and the observed maximum
3. deflection decreased by (21-28) \% for slabs (S32S33) respectively as figure (10).

4. For series (S4) the punching failure load decreased by $(8-34-62) \%$ and the observed maximum deflection decreased by $(6-11-15) \%$ for slabs (S44- S42- S43) respectively as Figure (11).

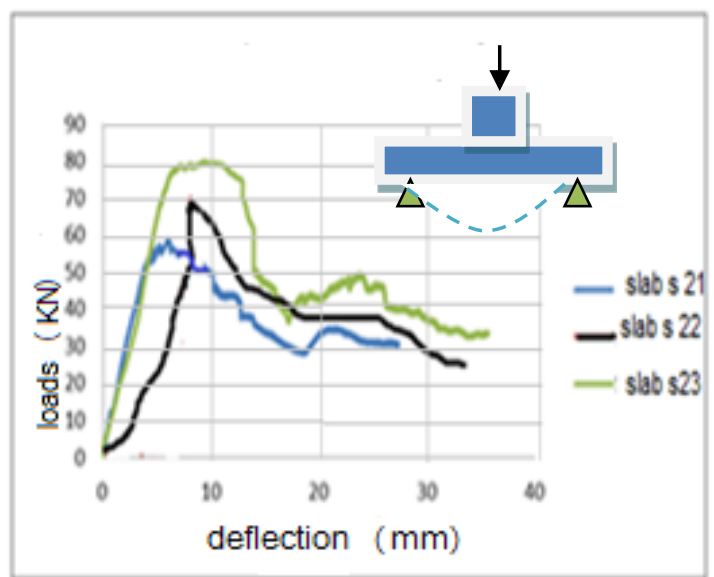

Figure (9): The load-deflection - curves for slabs S2

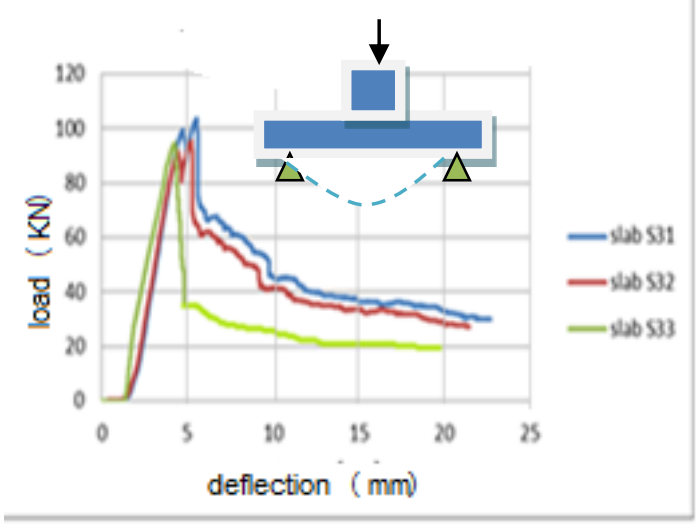

Figure (10): The load-deflection - curves for slabs S3

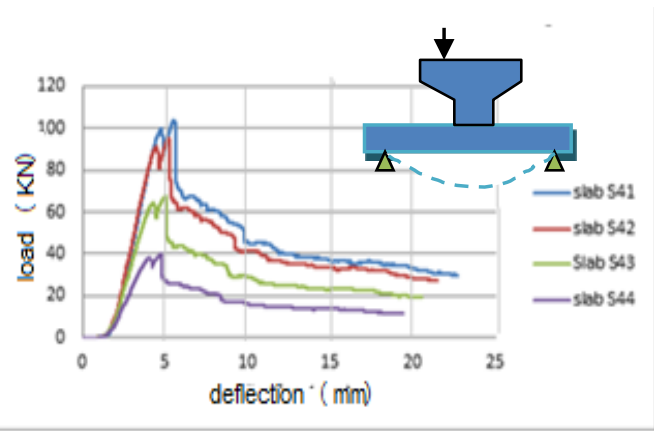

Figure (11): The load-deflection - curves for slabs S4 


\begin{tabular}{|c|l|c|l|l|c|c|}
\hline \multicolumn{7}{|c|}{ Table (2): The results of the experimental study for all tested slabs } \\
\hline $\begin{array}{c}\text { Sample } \\
\text { No. }\end{array}$ & $\begin{array}{l}\text { Maximum } \\
\text { deflection } \\
(\mathrm{mm})\end{array}$ & $\begin{array}{l}\text { Deflection } \\
\text { at 20\% from } \\
\text { max. load } \\
(\mathrm{mm})\end{array}$ & $\begin{array}{l}\text { Ultimate } \\
\text { load (Vu) } \\
(\mathrm{KN})\end{array}$ & $\begin{array}{l}\text { First } \\
\text { cracking } \\
\text { load } \\
\text { Vfirst) } \\
\text { KN }\end{array}$ & $\begin{array}{c}\text { V first } \\
\text { V u } \\
(\%)\end{array}$ & $\begin{array}{l}\text { Ductility } \\
\text { index }(*)\end{array}$ \\
\hline S11 & 3.979 & 3.65 & 40 & 14 & 35 & 1.09 \\
\hline S21 & 9.165 & 8.7 & 58 & 10 & 17 & 1.05 \\
\hline S22 & 8.5 & 8.2 & 70 & 14 & 20 & 1.0365 \\
\hline S23 & 8.2 & 7.97 & 80 & 20 & 25 & 1.029 \\
\hline S31 & 7.7 & 5.2 & 103.68 & 40 & 38.8 & 1.48 \\
\hline S32 & 4.5 & 4.1 & 92.015 & 36 & 39.1 & 1.097 \\
\hline S33 & 4 & 3.7 & 86 & 25 & 29 & 1.08 \\
\hline S41 & 7.7 & 5.2 & 103.6 & 40 & 38.8 & 1.48 \\
\hline S42 & 7.25 & 5 & 95.2 & 36 & 37.8 & 1.45 \\
\hline S43 & 6.89 & 6.3 & 67.38 & 23 & 34.13 & 1.093 \\
\hline S44 & 6.57 & 6.13 & 39.75 & 12.65 & 31.8 & 1.07 \\
\hline
\end{tabular}

(*) Ductility index was calculated as a ratio between the maximum deflection and the deflection at $20 \%$ from the maximum loads

\subsection{Crack pattern and failure criteria}

The eccentric punching shear loads affect the size, location of cracks. When the loads are increased, the radial cracks are directed to the wide perimeter, and the tangential cracks moving to the slab edges. Such as the crack shape of the specimen (S21) as Figure (12). The slabs (S22, S23) have a different shape of radial cracks around the center of the slab under the applied load because of the presence of additional reinforcement as Figure (13, 14, and 15a). For slabs $\mathrm{S} 4$ at the failure when considering eccentric loading, are presented at zero, 50, 70 and $100 \mathrm{~mm}$ respectively. The intensity of cracks reduced when the slabs exposed to eccentric loads so the failure load was small as Figure(15-b).

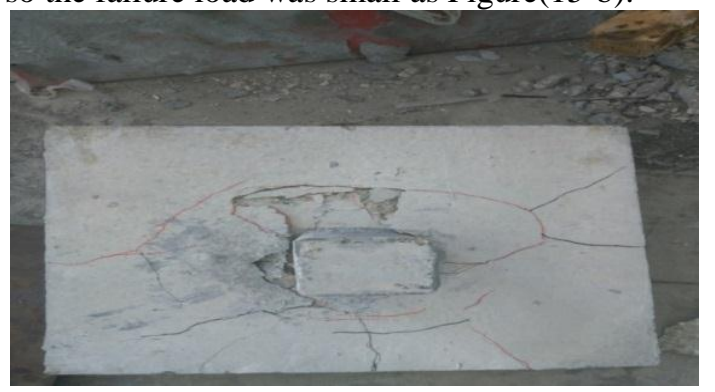

Figure (12): Shape of failure for slab S 21

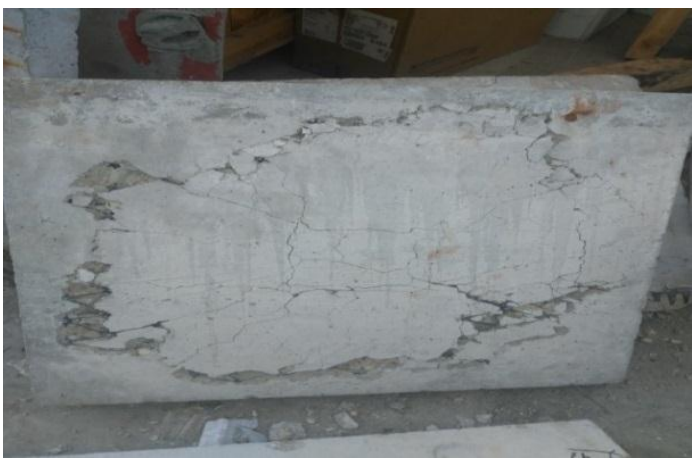

Figure (13): Shape of failure for slab S 22

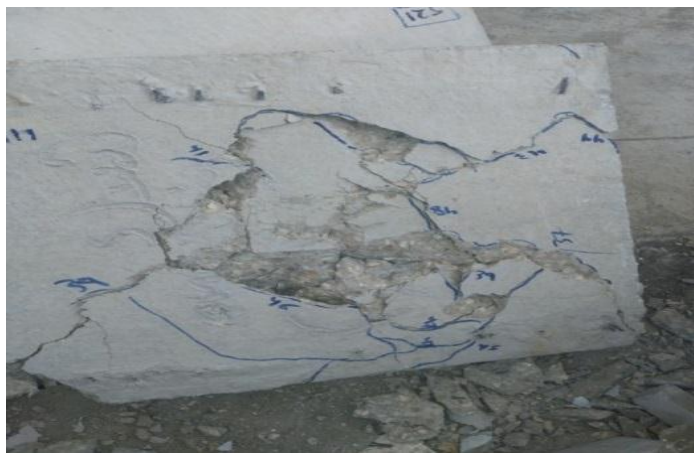

Figure (14): Shape of failure for slab S 23 


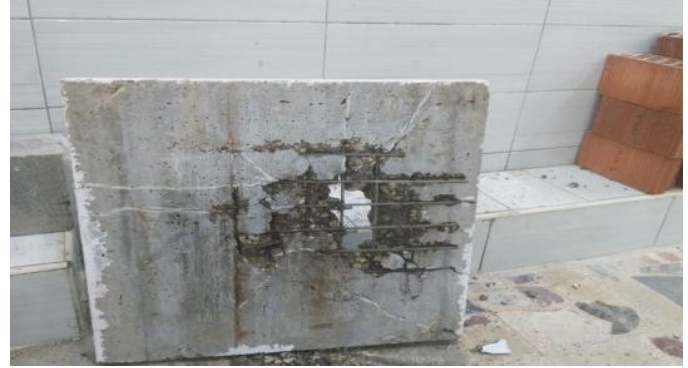

Figure(15-a): The crack pattern for slabs S3

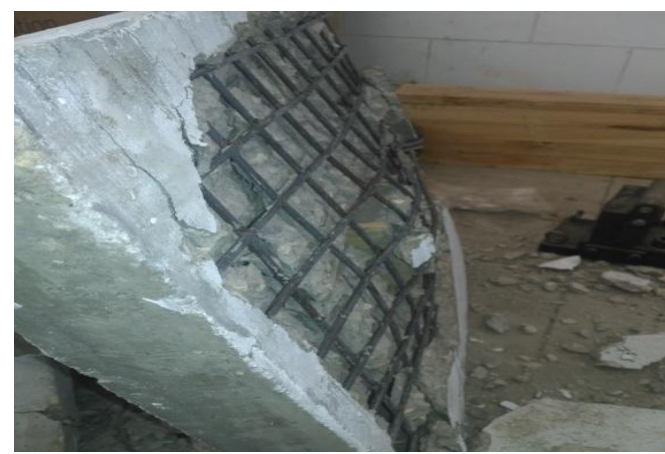

Figure(15-b): The crack pattern for slabs S4

\subsection{Effect of load Eccentricity}

For the group series S4 which includes (S 41) as a control slab with applied load at the center of slab column connection, the other slabs ( S42, S 43 , S 44 ) tested under vertical shear punching force applied at eccentricity of $(50,70,100) \mathrm{mm}$ respectively which generated a moment transfer in slab column connection. Significantly the existing off moment transfer leads to reducing the punching load capacity of the slabs as shown in Table (3). It can be noticed by the load-deflection relationships for slabs (S4) as Figure (17)limited to the scope of this research. Three proposed equations for the relationships between the load and eccentricity are as follows:

$$
\begin{aligned}
& \mathrm{K}=-0.0648 \frac{\mathrm{e}}{\mathrm{t}}+0.1324 \\
& \text { For } 0 \leq \frac{\mathrm{e}}{\mathrm{t}} \leq 0.167 \\
& \mathrm{~K}=-0.533 \frac{\mathrm{e}}{\mathrm{t}}+0.212
\end{aligned}
$$

$$
\text { For } 0.167 \leq \frac{\mathrm{e}}{\mathrm{t}} \leq 0.233
$$

$$
K=-0.352 \frac{\mathrm{e}}{\mathrm{t}}+0.168
$$

$$
\text { For } 0.233 \leq \frac{\mathrm{e}}{\mathrm{t}} \leq 0.33
$$

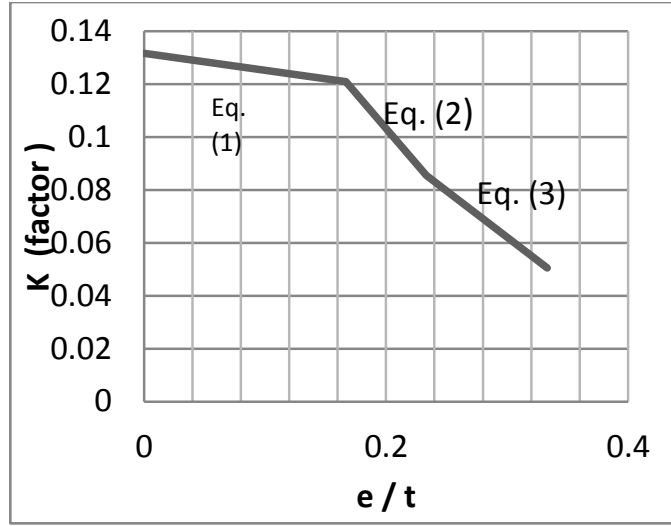

Figure (17): Relationship between (K) and (e/t).

Where $\mathrm{k}=\frac{\mathrm{P}_{\mathrm{u}}}{\mathrm{F}_{\mathrm{cu}} * \mathrm{bo} * \mathrm{~d}} \quad$ (dimensionless factor)

- Increasing the moment intensity increases the cracks and reduces the slab stiffness.

- With the higher bending moment applied on tested slabs(S44) have the least ductility index (1.07) with ratio ( 28 ) \% less than the ductility index of a slab ( S41).

- In slabs exposed to eccentric loads, it was noticed that the perimeter of shear failure zone increased by about (4.3- $9 \%$ ) compared with reference slab (S41) which exposed to a concentric load.

\subsection{Effect of Additional Flexure Reinforcement.}

From load-deflection curves, It can be observed that increasing the reinforcement ratio increases the slab stiffness and reduces the ductility index by $(1.2-2) \%$ for slabs $(\mathrm{S} 22, \mathrm{~S} 23)$ respectively. The specimens with additional reinforcement, the deflection has been considerably reduced by (7-10) $\%$ for slabs (S22, S23) respectively. The load capacity is increased by (21-38) \% for slabs (S22, S23) respectively compared with the control slab (S21) due to additional reinforcement provided.

\subsection{The influence of Eccentricity Proposed by Design Codes}

Table (4) shows the value of the experimental ultimate shear punching load (Vexp.) which compared with the shear punching force capacity calculated according to the Egyptian code for design which will be referred as (ECP). It can be observed that an increase in the eccentricity by $(50$ $-70-100) \mathrm{mm}$ reduces the ultimate shear punching force capacity by ratio $(34-42-63) \%$ as Figure (18). The number of shear stresses due to moment transfer $\left(q_{t}\right)$ was increased by ratio (29 -36 
- 42) \%. For the experimental results, those values of $\left(q_{t}\right)$ were increased by a ratio $(8-35-62)$ for eccentricity $\left(\begin{array}{lll}50 & -70 & -100\end{array}\right) \mathrm{mm}$ respectively as Figure(20). The 3 -factors for different eccentricities have been estimated for the internal column connection based on the ECP code and results presented in Table(5). By using equations (4,5and 6) for the experimental results an eccentricity of $(50-70-100) \mathrm{mm}$ gave an approximate factor (z) of $\left(\begin{array}{lll}1.09 & -1.53 & -2.59\end{array}\right)$ respectively. As shown in Figure(19) for eccentricity about $(55 \mathrm{~mm})$ the approximate factor(z) will be (1.15).

$q_{p}=\frac{Q}{b_{0} \times d}+\frac{M * *^{* c}}{J}$

$q_{p}=q_{v}+q_{t}$

$\zeta=\frac{q_{p(\text { total })}}{q_{v}}$

$\mathrm{q}_{\mathrm{p}}$ : The total punching shear stress

$\mathrm{q}_{\mathrm{v}}$ : The punching stresses due to direct shear transfer

$\mathrm{q}_{\mathrm{t}}$ : The punching stresses due to moment transfer

Q: Direct shear force

M : The unbalanced moment

$\mathrm{V}$ : Fraction of the moment transferred by shear

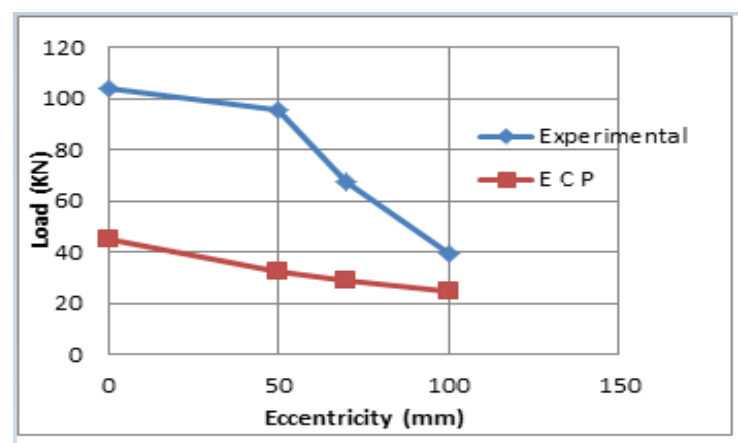

Figure (18): Load - eccentricity curves for Experimental and ECP results.

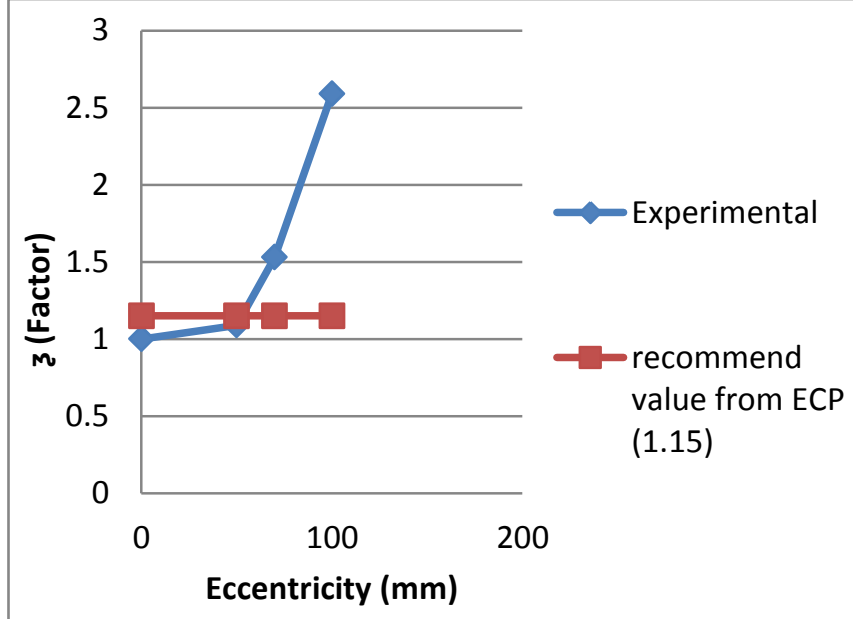

Figure (19): The relationships between factor $z$ and eccentricity

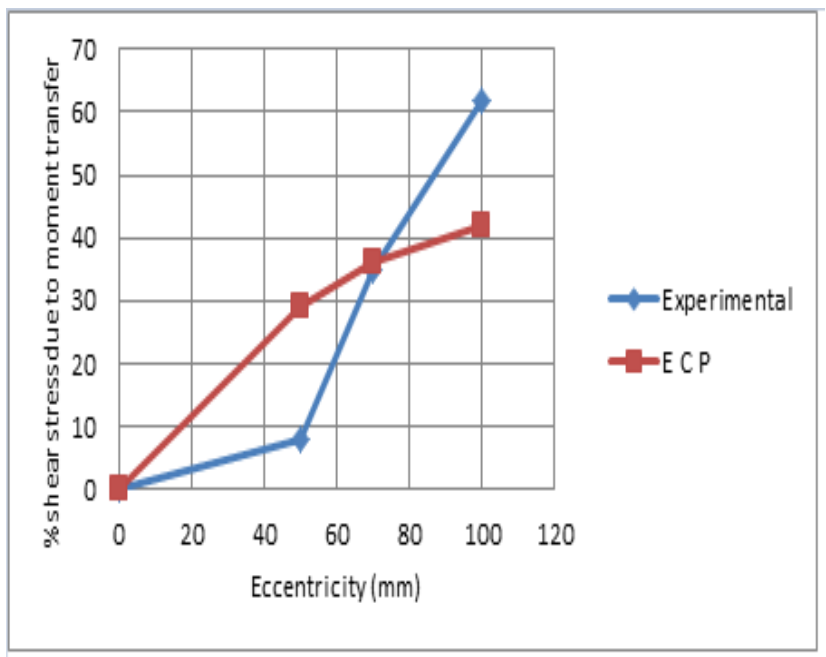

Figure (20): The relationships between increasing of shear stresses due to moment transfer and eccentricity

Table (3): The comparison results for slabs S4

\begin{tabular}{|c|c|c|c|c|c|c|}
\hline Sample No. & \multirow{2}{*}{ Fcu (Mpa) } & $\begin{array}{c}\text { Eccentricity } \\
(\mathrm{mm})\end{array}$ & $\begin{array}{c}\text { V u } \\
(\mathrm{KN})\end{array}$ & $\begin{array}{c}\text { Reduction } \\
\text { Ratio \% }\end{array}$ & $\begin{array}{c}\text { Ductility } \\
\text { index }\end{array}$ & $\begin{array}{c}\text { Failure area } \\
(\mathrm{mm})^{\mathbf{2}}\end{array}$ \\
\cline { 1 - 5 } S41 & \multirow{3}{*}{30} & 0 & 103.68 & ------- & 1.48 & 22000 \\
\cline { 1 - 5 } S42 & 50 & 95.2 & 8 & 1.45 & 22953 \\
\cline { 3 - 7 } S43 & 70 & 67.38 & 35 & 1.093 & 23873 \\
\cline { 3 - 7 } & & 100 & 39.75 & 62 & 1.07 & 24000 \\
\hline S44 & & &
\end{tabular}


Table (4): Shows the value of the experimental load and load capacity from Egyptian code (ECP)

\begin{tabular}{|c|c|c|c|c|c|c|c|c|}
\hline $\begin{array}{c}\text { Series } \\
\text { no }\end{array}$ & $\begin{array}{c}\text { Sample } \\
\text { no }\end{array}$ & $\begin{array}{c}\text { Eccentricit } \\
\text { y } \\
(\mathrm{e}) \mathrm{mm}\end{array}$ & $\begin{array}{c}\mathrm{V} \\
\text { Exp } \\
(\mathrm{KN})\end{array}$ & $\begin{array}{c}\mathrm{V} \mathrm{ECP} \\
(\mathrm{KN}) \\
.\end{array}$ & $\begin{array}{c}\frac{\mathrm{Vexp}}{\mathrm{V} 41} \\
\%\end{array}$ & $\begin{array}{c}\frac{V E C P}{V S 41} \\
\%\end{array}$ & $\begin{array}{c}\frac{\mathrm{Vexp}}{\%} \\
\%\end{array}$ & $\begin{array}{c}\text { Reduction } \\
\text { ratio \% }\end{array}$ \\
\hline \multirow{3}{*}{$\mathrm{S} 4$} & $\mathrm{~S} 41$ & 0 & 103.68 & 45.15 & 100 & 100 & 2.290 & 44 \\
\cline { 2 - 9 } & $\mathrm{S} 42$ & 50 & 95.2 & 32.158 & 92 & 72 & 2.960 & 34 \\
\cline { 2 - 9 } & $\mathrm{S} 43$ & 70 & 67.38 & 28.839 & 65 & 64 & 2.336 & 42 \\
\cline { 2 - 9 } & $\mathrm{S} 44$ & 100 & 39.75 & 24.972 & 40 & 55 & 1.590 & 63 \\
\hline
\end{tabular}

\begin{tabular}{|c|c|c|c|c|c|c|c|c|c|}
\hline \multicolumn{10}{|c|}{ Table (5): Results of shear stresses due to moment transfer calculated according to ECP } \\
\hline \multirow{2}{*}{$\begin{array}{c}\text { Series } \\
\text { no }\end{array}$} & \multirow{2}{*}{$\begin{array}{c}\text { Sample } \\
\text { no }\end{array}$} & \multicolumn{2}{|c|}{$\begin{array}{l}\text { ECP results } \\
\text { stresses (N/ } \\
\left.\mathrm{mm}^{2}\right)\end{array}$} & \multirow{2}{*}{$\begin{array}{l}\% \text { shear } \\
\text { stress due to } \\
\text { moment } \\
\text { transfer }\end{array}$} & \multicolumn{3}{|c|}{$\begin{array}{l}\text { Experimental results } \\
\text { stresses }\left(\mathrm{N} / \mathrm{mm}^{2}\right)\end{array}$} & \multirow{2}{*}{$\begin{array}{l}\text { \% shear } \\
\text { stress due } \\
\text { to } \\
\text { moment } \\
\text { transfer }\end{array}$} & \multirow{2}{*}{$z=\frac{q_{t o t a l}}{q_{v}}$} \\
\hline & & $q_{v}$ & $q_{t}$ & & $q_{\text {total }}$ & $q_{v}$ & $q_{t}$ & & \\
\hline \multirow{4}{*}{ S4 } & S41 & 1.73 & $\ldots \ldots$ & $\ldots \ldots$ & 3.97 & 3.97 & 0 & ..... & 1 \\
\hline & S42 & 1.23 & 0.5 & 29 & 3.97 & 3.64 & 0.33 & 8 & 1.09 \\
\hline & S43 & 1.1 & 0.63 & 36 & 3.97 & 2.58 & 1.39 & 35 & 1.53 \\
\hline & S44 & 1 & 0.73 & 42 & 3.97 & 1.53 & 2.44 & 62 & 2.59 \\
\hline
\end{tabular}

\subsection{American Concrete Institute Building}

\section{Code ( ACI 318-08)}

Depending on the position of a column concerning the slab edges. The results for punching shear capacity calculated according to (ACI) code which compared with the tested failure loads were mentioned in Figure (21) and Table (6). The basic relationship is:

$\mathbf{V u}=\frac{\mathrm{Vu}}{A c}+\frac{\gamma * M u * C}{J c}$

$\mathrm{Vu}=$ absolute value of the direct shear force

$\mathrm{Mu}=$ unbalanced column moment

$\mathrm{Ac}=$ area of concrete of assumed critical section

$\mathrm{V}=$ Fraction of the moment transferred by shear

$\mathrm{C}=$ Distance from centroid axis of critical section to the perimeter of the critical section

$\mathrm{Jc}=$ A geometry property of critical section, analogs to a polar moment of inertia of segments forming area Ac

From Table (7) it's observed that the number of shear stresses due to the moment transfer with different eccentricities were increased by ratio ( 54 $-63-70) \%$ according to ACI results, on the other hand, those ratios were $(8-35-62) \%$ for the experimental results. It was observed that the amount of shear stress due to moment transfer based on ACI code was more conservative than the Egyptian code especially for big eccentricities as shown in Figure (22, and (25)).

\subsection{American Concrete Institute Building Code ( ACI 318-08)}

Depending on the position of a column concerning the slab edges. The results for punching shear capacity calculated according to (ACI) code which compared with the tested failure loads were mentioned in Figure (21) and Table (6). The basic relationship is:

$\mathbf{V u}=\frac{\mathbf{V u}}{A c}+\frac{\gamma * M u * C}{J c}$ 


\subsection{American Concrete Institute Building \\ Code ( ACI 318-08)}

Depending on the position of a column concerning the slab edges, the results for punching shear capacity calculated according to (ACI) code are compared with the tested failure loads and mentioned in Figure (21) and Table (6). The basic relationship is:

$\mathbf{V u}=\frac{\mathbf{V u}}{A c}+\frac{\gamma * M u * C}{J c}$

$\mathrm{Vu}=$ absolute value of the direct shear force

$\mathrm{Mu}=$ unbalanced column moment

Ac $=$ area of concrete of assumed critical section

$\mathrm{V}=$ Fraction of the moment transferred by shear

$\mathrm{C}=$ Distance from centroid axis of critical section to the perimeter of the critical section

$\mathrm{Jc}=\mathrm{A}$ geometry property of critical section, analogs to a polar moment of inertia of segments forming area Ac

From Table (7) it's observed that the number of shear stresses due to the moment transfer with different eccentricities were increased by ratio (54 $-63-70) \%$ according to ACI results, on the other hand, those ratios were (8- 35- 62)\% for the experimental results. It was observed that the amount of shear stress due to moment transfer based on ACI code was more conservative than the Egyptian code especially for big eccentricities as shown in Figure (22, and (25)).

\subsubsection{Comparison between the experimental results, the ECP code, and ACI codes.}

The manner to take into account an eccentricity of the load varies from code to another. The codes introduce a linear relation for the existing of the force and flexure moment Figures $(23,24)$. From figure (25) and table (8), the relation between the loads' ratios for (Experimental, ECP, and ACI) and the variable eccentricity. It can be observed that the ACI code has a good agreement with experimental results more than the ECP code especially for the big eccentricity (100)mm.

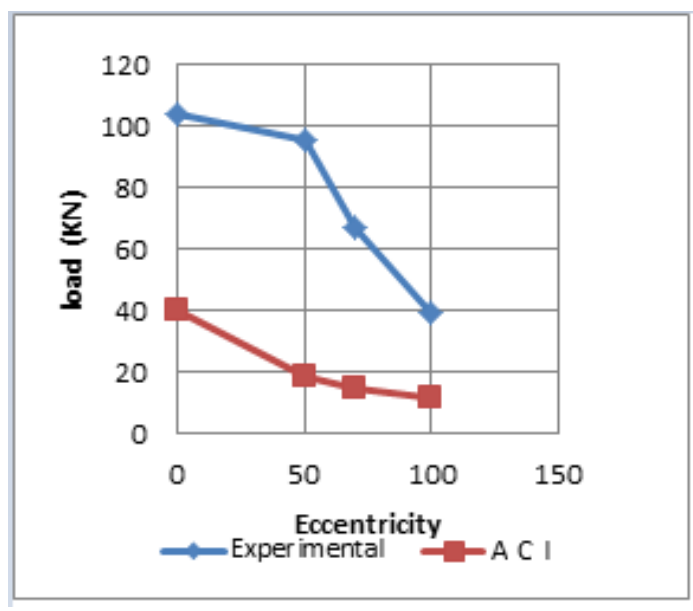

Figure (21): The relationships of eccentricity, loads S4 and $\mathrm{V}$ (ACI)

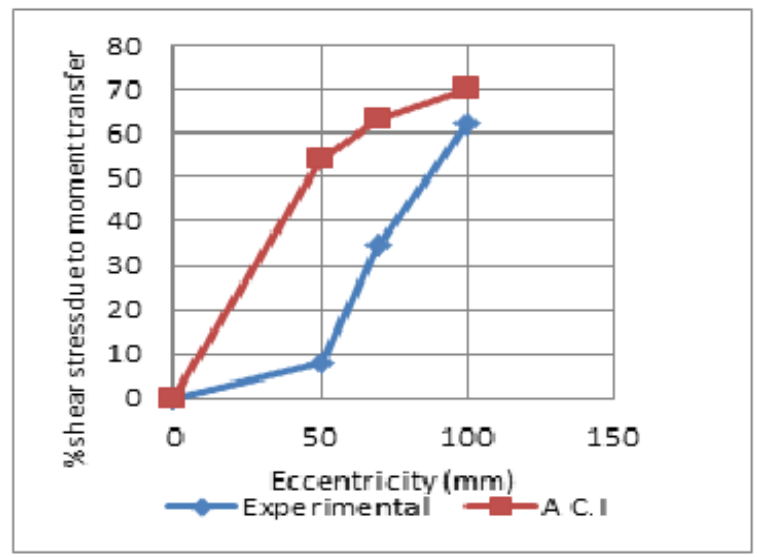

Figure (22): The relationships between increasing of shear stresses due to moment transfer and eccentricity 


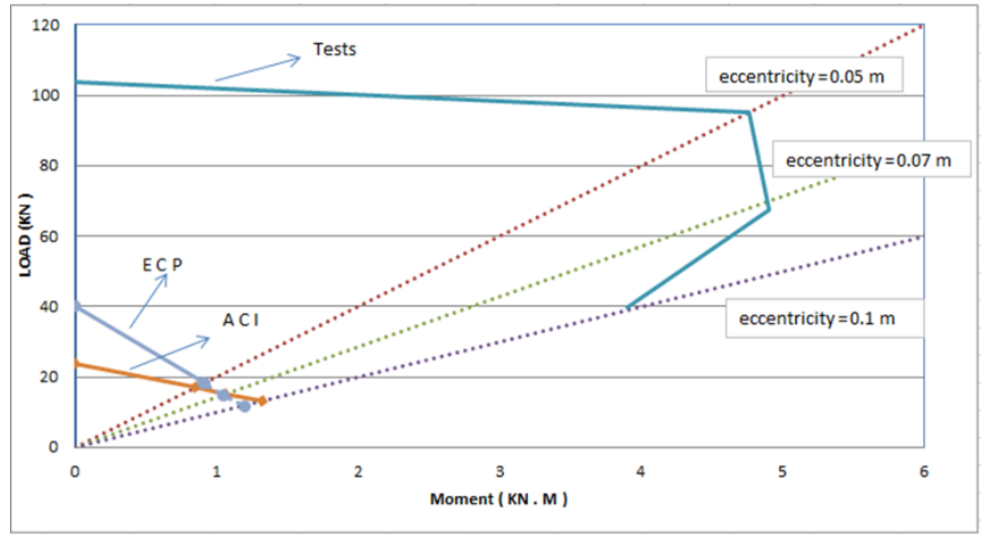

Figure (23): Influence of eccentricity according to codes

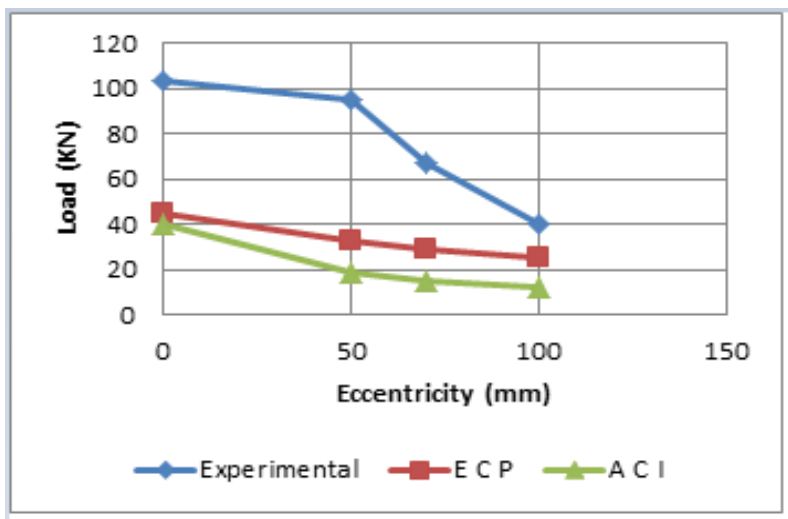

Figure (24): Comparison of the calculated capacity load using Exp. And different codes

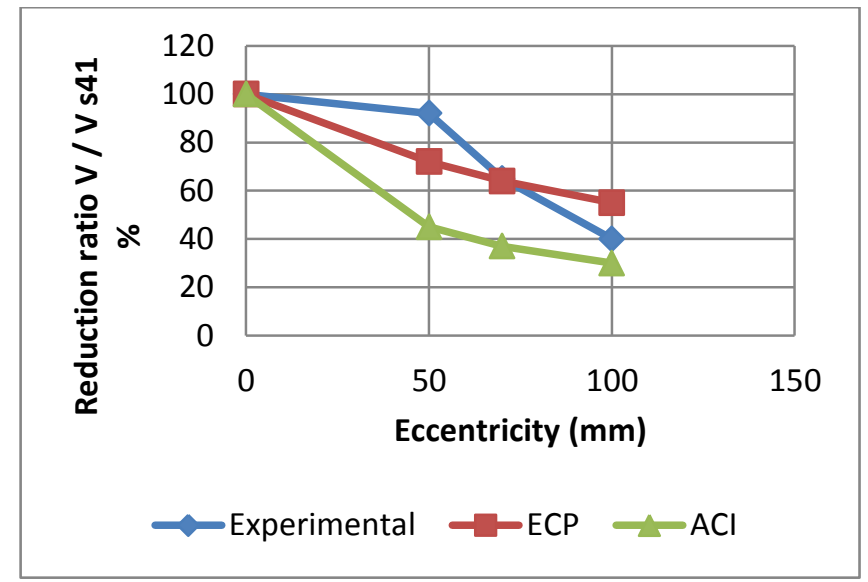

Figure (25): Failure load reduction ratios for different eccentricities when compared to control specimen 


\begin{tabular}{|c|c|c|c|c|c|}
\hline $\begin{array}{l}\text { Sample } \\
\text { No. }\end{array}$ & $\begin{array}{l}\text { Eccentricity } \\
\text { (e ) } \mathrm{mm}\end{array}$ & $\begin{array}{l}\mathrm{V} \exp \\
(\mathrm{KN})\end{array}$ & $\begin{array}{l}\mathrm{V} \\
(\mathrm{ACI}) \\
(\mathrm{KN}) \\
\end{array}$ & $\frac{\text { Vexp }}{\text { ACI }}$ & $\left.\begin{array}{l}\text { Reduction ratio } \\
\%(V A C I / V \exp \end{array}\right)$ \\
\hline SS41 & 0 & 103.68 & 40.4 & 2.56 & 40 \\
\hline S42 & 50 & 95.2 & 18.3 & 5.2 & 20 \\
\hline S43 & 70 & 67.38 & 15 & 4.492 & 22 \\
\hline S44 & 100 & 39.75 & 12 & 3.32 & 30 \\
\hline
\end{tabular}

\begin{tabular}{|c|c|c|c|c|c|c|c|c|c|}
\hline \multicolumn{10}{|c|}{ Table (7). The results of shear stress from experimental and ACI code values } \\
\hline \multirow{2}{*}{$\begin{array}{l}\text { SERIES } \\
\mathrm{NO}\end{array}$} & \multirow{2}{*}{$\begin{array}{l}\text { SAMPLE } \\
\text { NO }\end{array}$} & \multirow{2}{*}{$\begin{array}{l}\mathrm{V} \\
\exp \\
(\mathrm{KN})\end{array}$} & \multirow{2}{*}{$\begin{array}{l}\text { V } \\
\text { A C I } \\
(\mathrm{KN}) \\
\end{array}$} & \multicolumn{2}{|c|}{$\begin{array}{l}\text { A C I results in } \\
\text { stress }\left(\mathrm{N} / \mathrm{mm}^{2}\right)\end{array}$} & \multirow{2}{*}{$\begin{array}{l}\% \text { shear } \\
\text { stress due to } \\
\text { moment } \\
\text { transfer }\end{array}$} & \multicolumn{2}{|c|}{$\begin{array}{l}\text { Experimental } \\
\text { results stress } \\
\left(\mathrm{N} / \mathrm{mm}^{2}\right)\end{array}$} & \multirow{2}{*}{$\begin{array}{l}\text { \% shear } \\
\text { stress due } \\
\text { to } \\
\text { moment } \\
\text { transfer }\end{array}$} \\
\hline & & & & $\mathrm{qv}$ & $\mathrm{qt}^{\mathrm{t}}$ & & $\mathrm{qv}$ & $\mathrm{qt}^{\mathrm{t}}$ & \\
\hline \multirow{4}{*}{ S4 } & S41 & 103.68 & 40.4 & 1.83 & ------- & 0 & 4.7 & -------- & 0 \\
\hline & $\mathrm{S} 42$ & 95.2 & 18.3 & 0.83 & 1 & 54 & 4.32 & 0.38 & 8 \\
\hline & S43 & 67.38 & 15 & 0.68 & 1.15 & 63 & 3.05 & 1.65 & 35 \\
\hline & S44 & 39.75 & 12 & 0.54 & 1.29 & 70 & 1.8 & 2.9 & 62 \\
\hline
\end{tabular}

\begin{tabular}{|c|c|c|c|c|c|c|c|c|}
\hline \multicolumn{9}{|c|}{ Table (8): The value of the experimental load and load capacity from Egyptian code (ECP) } \\
\hline $\begin{array}{c}\text { Series } \\
\text { no }\end{array}$ & $\begin{array}{c}\text { Sample } \\
\text { no }\end{array}$ & $\begin{array}{c}\text { Eccentricity } \\
\text { (e ) } \mathrm{mm}\end{array}$ & $\begin{array}{l}\text { Vexp } \\
(\mathrm{KN})\end{array}$ & $\begin{array}{l}\text { V ECP } \\
(\mathrm{KN}) .\end{array}$ & $\begin{array}{c}\mathrm{V}(\mathrm{ACI}) \\
(\mathrm{KN}) .\end{array}$ & $\begin{array}{c}\frac{V \exp }{V s 41} \\
\%\end{array}$ & $\begin{array}{c}\frac{V E C P}{V S 41} \\
\%\end{array}$ & $\begin{array}{c}\frac{V A C I}{V S 41} \\
\%\end{array}$ \\
\hline \multirow{4}{*}{ S4 } & S41 & 0 & 103.68 & 45.15 & 40.4 & 100 & 100 & 100 \\
\hline & S42 & 50 & 95.2 & 32.158 & 18.3 & 92 & 72 & 45 \\
\hline & S43 & 70 & 67.38 & 28.839 & 15 & 65 & 64 & 37 \\
\hline & S44 & 100 & 39.75 & 24.972 & 12 & 40 & 55 & 30 \\
\hline
\end{tabular}




\section{CONCLUSIONS}

Based on the conducted experimental work and the predicted punching shear loads from different codes, the following could be concluded.

1. The punching shear failure load was reduced by $8 \%$ to $62 \%$ according to the increase of column load eccentricity from $50 \mathrm{~mm}$ to $100 \mathrm{~mm}$, respectively.

2. The column eccentricities have adverse effect on the slab ductility. The ductility was decreased by ratios from $2 \%$ to $28 \%$ according to the increase of column eccentricity.

3. The predicted punching shear capacities of slabs using either ECP or ACI codes were lesser than those from experimental results by ratios ranging from $34 \%$ to $70 \%$ according to increase of column eccentricity.

4. The ECP code results are more accurate while ACI results are more conservative for the punching shear stresses due to moment transfer contribution, specially at high eccentricities.

\section{REFERENCES}

[1] Regan, P.E., Sep.1986, "Symmetric Punching of Reinforced Concrete Slabs", Magazine of Concrete Research, Vol. (38), No.(13), pp.115-128

[2] Rankin, G.I.B. and Long, Apr. 1987, "Predicting the Punching Strength of Conventional SlabColumn Specimens", Proceeding of Institute of Civil Engineering, London, Vol. (82), pp.327-346.

[3] Banthya, N, Al-Asally, (1995). "Behavior of Concrete Slabs Reinforced with Fiber-Reinforced Plastic Grid." ASCE Journal of Material in Civil Engineering, 7(4), pp.: 252-257.

[4] ACI Committee 318. (2014) "Building Code Requirements for Structural Concrete and Commentary", ACI 318-15.

[5] Ngo, D. T., 2001, "Punching shear resistance of high-strength concrete slabs", Journal of Structural Engineering, pp.52-59, The University of Melbourne, Australia.

[6] Islam, S. and Park, R., March 1976, "Tests on SlabColumn Connections with Shear and Unbalanced Flexure", Journal of ASCE, Vol. (102), pp 549-568

[7] Bu, W., 2008, "Punching Shear modified Method with Shear Bolts for flat Slabs under Seismic Loading", Ph.D. thesis, University of Waterloo, Canada.

[8] Zhang, Q., "The Punching Strength of High Strength Flat plates with Experimental Study", University of Memorial, Newfoundland, December 2004, pp. 1-20
[9] Al-Ani, M. A.R. M., 1985, "Effect of Steel Fibers on Punching Shear Strength of flat reinforced Slabs", University of Baghdad.

[10] Schreiber, S.K., "Punching Shear Capacity of Slab with Steel Fiber Reinforcement under Lateral Cyclic Loading", M.Sc. Thesis, Department of Civil and Environmental Engineering, University of Alberta, Edmonton, Spring, 2001, pp. 1- 20

[11] Teng, S., 1999, Irregular Flat Plate Structures", BCA-NTU research project, Nan yang Technological University

[12] Alexander, S.D.B., and Simmons, S.H. (1992). "Tests of Column-Flat Plate Connections", ACI Structural Journal, 89 (5), pp.: 495-502

\section{LIST OF SYMBOLS:}

$\mathrm{Vu}$ : Absolute value of the direct shear force.

$\mathrm{Mu}$ : unbalanced column moment.

Ac :Area of concrete of assumed critical section

$\mathrm{V}:$ Fraction of the moment transferred by shear

$\mathrm{C}$ : Distance from centroid axis of critical section to the perimeter of the critical section.

Jc : A geometry property of critical section, analogs to a polar moment of inertia of segments forming area Ac.

$\mathrm{q}_{\mathrm{p}}$ : The total punching shear stress

$\mathrm{q}_{\mathrm{v}}$ : The punching stresses due to direct shear transfer

$\mathrm{q}_{\mathrm{t}}$ : The punching stresses due to moment transfer

Q : Direct shear force 